\title{
Articles
}

\section{Cases in TESOL Teacher Education: Creating a Forum for Reflection}

Jane Jackson

\begin{abstract}
This article reviews the case method from an historical perspective and explores why and how "decision" cases might be used by teacher educators in the professional preparation of teachers as reflective ESOL specialists. It is argued that the case method can sharpen the critical thinking, analytical, and communication skills of both novice and experienced teachers and help ready them for the complex challenges they could face in the world of professional practice. Enthusiasm for this methodology, however, is tempered with words of caution about the difficulties involved in implementing case-based learning in teacher education programs. Guidelines for selecting and using "decision" cases are provided and recommendations are made for future developments in case-based teaching and learning in TESOL. Three appendixes include sources for teaching cases and details about a working conference for case facilitators and writers.
\end{abstract}

Teaching cases have long been a cornerstone of professional preparation in schools of law, business, and medicine. Teacher educators have also been exploring their value in the preparation of teachers, although relatively few TESOL specialists have ventured into case-based teaching, writing, and research (Asbaugh \& Kasten, 1995; Doyle, 1990; Jackson, 1996a, 1996b; Kleinfeld, 1992; Merseth, 1991a; Shulman \& Colbert, 1988). This article is based on the belief that TESOL teacher education programs can benefit from what colleagues in other disciplines have discovered and published about case writing and teaching. The case method, I argue, is particularly suited to the analysis of the complex issues and situations that ESOL teachers routinely face. Thus this article briefly describes the principles, benefits, and challenges involved in implementing case-based learning in programs that are designed to prepare teachers as reflective ESOL specialists.

\section{Historical Roots of the Case Method}

Case method teaching has for over 100 years been incorporated into professional preparation programs as one means of narrowing the gap between theoretical knowledge and practice. In 1870 the case method was introduced in the Harvard University Law School where the objective of the method was to teach legal principles (Merseth, 1991b). Law instructors questioned stu- 
dents in a way so as to guide them to the predetermined "right" answers or decisions in actual court cases. By 1915 this variation of the case method was the primary mode of instruction in most of the well-known law schools in the United States (Culbertson, Jacobson, \& Reller, 1960).

In the 1920s the case method became popular in the Harvard Business School and then spread to business schools across North America and beyond (Knirk, 1991; Osigweh, 1989). Instructors in this field have traditionally used cases quite differently from their colleagues in law. Business cases are primarily used to teach students how to analyze problems and to determine and evaluate appropriate courses of action (Cooper, 1995; Hammond, 1980; Kleinfeld, 1990). The cases most often represent actual problems that have confronted managers, and they are carefully constructed to stimulate discussion and analysis in order to help students better understand the complex factors involved in business management. In contrast with legal education, business instructors do not guide students to the "right" answers; instead, they use questions to encourage students to identify and critically examine various action plans and their consequences. Interaction among business students is actively encouraged by the case leader, and different viewpoints are welcomed (Christensen \& Hansen, 1994; Cooper, 1995).

Cases were introduced in the Harvard Medical School in the early 1900s where it is now the primary instructional method in the training of doctors. Several medical schools in Canada have also become well known for their case method or problem-based training programs where medical students analyze the physical or emotional problems of patients (cases) in small tutorial groups (7-8 students) to develop their clinical, analytical, and communication skills (Wassermann, 1994a).

Compared with professional education in law, business, and medicine, the use of cases in the preparation of teachers played a relatively minor role until the 1986 American publication of A Nation Prepared: Teachers in the 21st Century (Shulman, 1992). This landmark report by the Carnegie Task Force on Teaching as a Profession urged teacher education programs to include teaching cases that illustrate a wide variety of teaching problems in order to "provide opportunities for prospective teachers to grapple with the ambiguities and dilemmas of schooling, such as grading, racism, plagiarism, diversity, appropriate instruction, and uncooperative students" (p. xiv).

Since the late 1980s many teacher educators have heeded this call and have been exploring the use of the case method in preparing teachers. It has now become possible to select from a growing array of casebooks (collections of teaching cases) that are aimed at the preparation of preservice and inservice elementary, secondary, and special education teachers as well as school administrators. To my knowledge, however, only one commercial casebook is now targeted at ESOL teachers, ESOL Case Studies: The Real World of L2 Teaching and Administration by Plaister (1993). It includes some short cases or 


\begin{abstract}
"vignettes" that deal with issues that are directly related to the teaching of ESL, EFL, and ESP. A welcome addition will be Teaching in Action: Case Studies from Second Language Classrooms edited by Richards (in press).

With the availability of casebooks in general education has come the establishment of centers of case development for teacher education programs. Some of these centers include cases that deal with issues in ESOL or multicultural classrooms, although none is primarily concerned with the collection and distribution of TESOL case materials (see Appendix B for a list of case clearinghouses in Canada and the United States).
\end{abstract}

\title{
What Are Cases?
}

A good case is the vehicle by which a chunk of reality is brought into the classroom to be worked over by the class and the instructor. A good case keeps the class discussion grounded on some of the stubborn facts that must be faced in real life situations. It is the anchor on academic flights of speculation. It is the record of complex situations that must be literally pulled apart and put together again before the situations can be understood. It is the target for the expression of attitudes or ways of thinking brought into the classroom. (Lawrence, 1953, p. 215)

The definition and goals of case-based teaching in teacher education have continued to evolve since Lawrence (1953) first offered his views about what constitutes a case. Today a great deal of variation exists in the contexts, characters, situations, and behaviors described in cases; the format in which the case materials are presented; the ways in which the teacher educators and students engage in these activities; and the rationales for and goals of casebased teaching (Jackson, 1996c; Sykes \& Bird, 1992). For example, cases can be employed "to teach new information, concepts, and theories (e.g., showing that conflict is prevalent in organizations); or they can be a vehicle for applying acquired knowledge and skills in specific situations (e.g., reasoning, critical thinking, and problem-solving exercises) (Weaver, Kowalski, \& Pfaller, 1994, p. 171).

Differences may also exist in the source (fact-based or simulation), media (print, video, multimedia), and length (a single paragraph to 15 pages or more) of the case materials. Some cases may be written or videotaped especially for use in teacher education programs, whereas other material such as journal articles, newspaper stories, videotaped lessons, curriculum or language policy reports, and so forth may have been prepared with a different audience and purpose in mind. In addition, some cases may conclude with a resolution, whereas others are purposely left open-ended. Finally, guiding questions may or may not be provided by the case-writer or course instructor. 
One type of case that is gaining popularity in teacher education programs today is the decision or decision-making case, which is patterned after the business school model and specifically designed to promote teacher reflection and problem solving (Merseth, 1992; Welty \& Silverman, 1995). Cases of this genre focus on dilemmas or critical incidents in teaching and are most often presented from the perspective of individuals or organizations that must make decisions related to those dilemmas (Merseth, 1992; Silverman \& Welty, 1995; Simmons, 1995). Decision cases, which are often in narrative form, are usually open-ended. Students are expected to become involved in the cases and make their own decisions while providing analyses and rationales to support their positions.

The remainder of this article focuses on the use of decision cases in TESOL teacher education programs. I draw on my experience as a case teacher and writer in three graduate-level teacher education courses at Saint Mary's University in Halifax: a general TESOL methodology course, a curriculum and instruction course for prospective ESP practitioners, and a course in cross-cultural communication. The students in these courses were Canadian as well as international students from such countries as China, Vietnam, Peru, the Philippines, and Lebanon. All of them had a minimum of one year of teaching experience before entering the Master of Education program in TESOL. Some had taught ESL in Canada or EFL abroad; others were new to our field. In short, they were a diverse group with varied goals and interests.

My ideas about the use of cases in TESOL courses have also been strongly influenced by my participation in an intensive interdisciplinary working conference on case-based teaching that was sponsored by the American Association of Higher Education (AAHE) Teaching Initiative and the Pace University Center for Case Studies in Education at the University of British Columbia (see Appendix $C$ for further information). It was at this conference that I was able to interact with and learn from colleagues who have been using cases in content teaching as well as in teacher education programs in such areas as nursing, business, law, and general/special education.

\section{Why Use Decision Cases?}

One of the most important goals of TESOL teacher education programs is to prepare student teachers for professional practice in a world that presents value conflicts, ambiguity, and perplexing decisions. Cases can illustrate how complex teaching actually is and better prepare novice teachers for an "ill-structured domain" where there are few clear right or wrong courses of action (McRobbie \& Shulman, 1991, p. 1). With practice in analyzing cases, individually and in groups, students can gradually learn to think and react like professionals (Feiman-Nemser, 1990; Schön, 1987).

In The Reflective Teacher (1983), Schön calls for teacher educators to create a "forum for reflection" whereby student teachers are immersed in the "com- 
plexity, uncertainty, instability, uniqueness, and value conflicts, which are increasingly perceived as central to the world of professional practice" (p. 14). In TESOL in the last two decades we have seen an increasing emphasis on developing "reflective practitioners," that is, ESOL teachers who go through a thinking process in which they critically examine decisions and actions in their teaching situations (Hutchings, 1993; Richards, 1991; Schön, 1983). The effective use of decision cases in teacher education programs can facilitate this process.

Case-based learning can move students to a new awareness of their own values and beliefs (Cossom, 1991) and an acceptance of views that are different from their own. Decision cases can provide a type of "classroom apprenticeship for professional decision-making" and introduce prospective teachers to the challenges of interacting and collaborating with students and professionals from different discourse communities and cultures (Asbaugh \& Kasten, 1995; Schön, 1983, 1987).

An important goal of case study is that through the processes of individual and group analysis, a broad range of alternatives will be generated and debated, new ways of looking at situations will be exposed, participants' attitudes and mind sets will be challenged, and decision-making skills will be encouraged through an active, participatory form of education. (Cossom, 1991, p. 144)

Decision cases can offer rich, dramatic accounts of the problems instructors, students, and administrators actually face in an ESOL context and can go a long way toward bridging the gap between theory and practice. The power of decision cases lies in the way they encourage students to look at dilemmas from the inside out and not simply to act as external critics of someone else's decision (Simmons, 1995). Furthermore, in this approach it is assumed that students bring with them relevant practical experience, theoretical knowledge, and principles that they must draw on as they analyze the case (Silverman, Welty, \& Lyon, 1992). This is very much in line with current thought about the importance of active learning in adult education programs and the value of student-generated analysis rather than teacher-manufactured solutions (Asbaugh \& Kasten, 1995; Richards \& Lockhart, 1994; Silverman et al., 1992; Wassermann, 1992, 1993).

To choose cases as a pedagogy, then, is to accept the concept that although theoretical principles may be important and must be learned by those who teach, simply knowing a principle is of limited value in the real world of professional practice. The incorporation of decision cases into TESOL teacher education curricula assumes that what we need are teachers who are prepared to put principles into practice and perhaps develop new ones (Kennedy, 1987; Kleinfeld, 1990; Merseth, 1991a, 1991b; Richards \& Lockhart, 1994; Schön, 1987). 


\section{Characteristics of Effective Decision Cases}

The selection of appropriate decision cases for a particular program of studies and group of students is not an easy task, yet it is crucial to the success of the learning experience. The following are some characteristics of decision cases that I have found to work particularly well in my MEd TESOL courses at Saint Mary's University.

1. A clear relationship exists between the primary ideas in the cases and the course syllabus (objectives, approach, and content).

2. The cases are well written, often in narrative form. They create strong interest and draw the students into the events discussed. The characters and their situation are credible so that the students can identify with and care about them.

3. The detailed narratives are "richly contextualized, multilayered accounts containing a variety of issues for analysis" as in the real world of professional practice (Sykes \& Bird, 1992, p. 464).

4. Engaging cases are somewhat ambiguous; they do not have easy or quick solutions because they deal with the complexities of real-life teaching situations. There are usually several reasonable ways to respond to the dilemmas (Asbaugh \& Kasten, 1995).

5. They end with a "kicker" - a crisis that is unresolved. "The dilemma may well be the hook in a case that alerts students to the complexity of issues and steers them away from the simplistic single answer that dominates much of classroom discussion. Good cases drive students' need to know" (Wassermann, 1994b, p. 607)

\section{What Issues Could ESOL Decision Cases Focus on?}

Because a case is a description of a real-life situation, it is a versatile medium and can be shaped to fit any theme or course of study. In a TESOL teacher education program, decision cases can be designed to put the student teacher firmly in the shoes of the ESOL teacher. These cases could focus on troublesome issues that routinely confront professionals in ESL or EFL situations such as the following.

\section{Curricular and Pedagogical}

- preparing a curriculum for a multilevel class;

- engaging in a curriculum development project with teachers who have different views about what the goals and objectives should be;

- designing materials with limited resources;

- teaching a listening-speaking class to students who are reluctant to speak;

- teaching a language lesson that falls flat.

Classroom Management

- dealing with unmotivated or overly shy students; 
- dealing with an incident of cross-cultural miscommunication or racism in the classroom;

- discovering that a student has plagiarized;

- attempting to use the communicative approach in a class of 50 multilevel students in China;

- introducing group work to students who consider it a waste of time;

- teaching in poor physical conditions in an unfamiliar cultural environment.

\section{Administrative and Personnel}

- interacting with school administrators and mainstream teachers who do not view language teachers as professionals;

- team teaching with ESOL teachers who have conflicting agendas;

- dealing with the pressures of being an itinerant ESL teacher in four elementary schools.

\section{How are Decision Cases Used in Teacher Education Programs?}

The following sequence outlines a pattern that I have followed in my casebased sessions in the MEd program at Saint Mary's University. It is one of the most typical patterns used by teacher educators today.

1. individual analysis and preparation;

2. optional informal small-group discussion (in or outside class);

3. full-class case discussion;

4. end-of-class generalization about the learning experience;

5. optional follow-up activity.

In this approach the students are presented with the case (reading, video, etc.) with the expectation that it will be studied thoughtfully in preparation for the class discussion. Individually or in study groups (in or out of class), students are required to tease out the relevant factors, analyze the problem(s) in the case, and make decisions based on careful assessment. This involves applying concepts, theories, knowledge, and wisdom that are helpful in untangling the situation and developing a plan of action for dealing with it.

Sometimes the students are provided with a few key questions that are designed to focus their analysis. Because the questions are intended to encourage creative and critical thinking, rather than suggest predetermined views about the case, they are often open-ended as in the following.

1. Why is this case a dilemma?

2. Who are the key players?

3. What are the main issues/ problems?

4. What if anything should $X$ do to resolve the dilemma?

5. What are the consequences of each solution?

6. What would you do if you were the decision-maker?

7. What did you learn from this case? 
After analyzing the case individually or in small groups, the students return to class and participate in a full-class discussion in which they interpret, analyze, and attempt to resolve the case. During this discussion, which may be completed in one class session or be extended over several sessions, the teacher assumes the role of facilitator, orchestra leader, and catalyst. The case discussion is driven by students' ideas and responses, and the facilitator has to be ready to deal flexibly with the often unpredictable, controversial, and sometimes heated discussion that develops (Christensen, 1991; Cossom, 1991; Wassermann, 1993, 1994b; Welty \& Silverman, 1995). The teacher must create an atmosphere in which all the students feel safe to be creative, express their ideas freely, risk responses that might differ from the majority opinion, and challenge others' views and assumptions of a case. The case teacher's "artistic management of the discussion ensures that issues of relevance-the big ideas-remain in the forefront of the discourse" (Wassermann, 1994b, p. 610). In this approach the teacher is called on to discourage vagueness and quick-fix solutions and provide summary statements at appropriate intervals (often in written form on chart paper or on a whiteboard).

In the real world of professional practice there are rarely perfect solutions to problems that ESOL teachers confront. Instead, there are usually several possible courses of action, each with strengths and limitations. Unless there is guidance from the teacher, students may all too easily opt for a quick solution without adequately examining the drawbacks of the ideas presented. It is in the whole class discussion, then, that the teacher must encourage students to examine critically the proposed solutions and their possible consequences and, in the process, guide the students to a deeper understanding of the issues involved.

A well-discussed case usually concludes with some common understandings of the key points in the case and a generalization about the learning experience (Asbaugh \& Kasten, 1995). By the end of a case-based learning session, students should have a clear idea as to why this particular case was selected for study, how it relates to the readings/lecture and the themes of the course, and what the main issues and possible solutions are. This debriefing is essential if students are to leave class with the feeling that the time and energy devoted to case analysis have been worthwhile.

After the debriefing, interest in the case should be high so that students feel motivated to learn more about the issues. If cases are carefully selected and sequenced, it is relatively easy to integrate a variety of worthwhile classroom activities/assignments into the course syllabus that build on the ideas presented and developed in the case analyses. For example, some cases may lead to individual or group postdiscussion activities such as reflective journal writing, written case reports, research papers on related topics, an assessment of the experience of working in groups, and student-generated cases. 
One activity that has proved valuable in my classes at Saint Mary's University has been the keeping of a reflective journal where students record their views about the case readings before meeting in groups and then, later, write about what they have discovered in the group/ whole class case analysis. As students hear the analysis of their peers, they become aware of ideas that might not have occurred to them when they were working on their own or in their small group. Keeping track of these ideas and how they have changed their ways of thinking about a situation moves students to a new awareness of their own value system and beliefs about teaching. It can take them a step closer to becoming reflective teachers.

\section{What Are the Benefits of Case-Based Learning?}

Working with decision cases can help novice teachers develop the skills needed by professional ESOL teachers or sharpen the skills of experienced teachers. In particular, through the process of case analysis, the participants can:

- Sharpen their overall communication skills: the ability to listen critically and with understanding; read with a purpose, synthesize information, make inferences, and speak and write more clearly, confidently, and persuasively;

- Develop their interpersonal and cooperative learning skills: learn how to deal with differences of opinion with colleagues; handle emotions and conflict more easily; learn how to share information and ideas and build constructively on the ideas of others;

- learn to apply and adapt conceptual and theoretical knowledge to real-life situations that are often complex and confusing;

- sharpen their analytical and problem-solving skills. Analyzing cases can help student teachers to think more clearly in the ambiguous or ill-structured situations of ESOL practice;

- Learn how to make judgments based on facts and clearly stated values rather than on hidden, unrecognized assumptions and personal biases;

- Develop their ability to see different courses of action in a given situation, make decisions among competing alternatives, examine the situation from the perspectives of different participants, and predict possible outcomes;

- Think like teachers as they become socialized to the world of ESOL teachers;

- Develop their ability and confidence to assess and evaluate both the process and product of their work in case study analysis (Asbaugh \& Kasten, 1995; Cossom, 1991; Jackson, 1996c; McKeachie, 1986).

Successful ESOL teachers need to have well-developed cross-cultural and interpersonal communication skills. Through the analysis of cases with students who have different ideas and experiences, students can learn to be- 
come more adept at handling conflicts. At Saint Mary's University, many of the MEd TESOL classes were made up of students from diverse cultures who brought with them their own value systems and world views. By working on ESOL cases with students from different backgrounds, students had a wonderful opportunity to be exposed to ideas that they might never otherwise have considered. Also, with experience in case analysis, students gradually developed the confidence and camaraderie necessary to be able to ask each other more probing, sensitive questions. This helped many to better understand and value the views of their classmates and, ultimately, recognize the culture-bound nature of their own positions.

\section{What Are the Limitations of Case-Based Learning?}

The case method, however, is not a panacea. Cases also have disadvantages that must be taken into account by individual teacher educators when deciding whether to adopt this methodology in their programs. The following list outlines some of the difficulties that need to be considered before adopting this problem-based approach to teaching and learning.

- The case method is not an easy instructional strategy to employ. The teacher's ability to use discussion teaching to help students to strive for a deeper understanding of the material has a great impact on whether the instructional process succeeds or fails (Christensen, 1991; Christensen \& Hansen, 1994) and, therefore, considerable preparation and practice are required before most teacher educators are competent and at ease in this situation;

- It takes longer to cover course content with cases than it does with lectures;

- Few cases in TESOL are readily available. Teacher educators must be resourceful in adapting or even writing their own cases; (see Appendixes A and B for a list of casebooks and case clearinghouses);

- Writing cases is a difficult and challenging literary task requiring effective writing skills and a clear understanding of the purpose of the exercise;

- In this student-centered method, the teacher gives up a good deal of control in the classroom. The nontraditional roles of facilitator, discussion leader, and catalyst may be uncomfortable for some teacher educators and not easily accepted by some students who may feel that the "experts" should be providing the "right" answers or solutions. This may result in a tense atmosphere in the classroom;

- Use of the case method in teacher education programs raises difficult issues of evaluation in terms of both the quality and quantity of students' performance and participation (Cossom, 1991).

Of course, the last item is of particular concern for both students and teachers. At the beginning of a course, students need to be made aware of 
how their performance in analyzing cases will be assessed. Whatever procedures are adopted, they should be consistent with the tenets of case-based learning. Traditional fact-based examinations, which may be easy to develop and mark, cannot adequately assess all of the skills that are emphasized in case-based learning. Because students are encouraged actively to participate, exercise their analytical, problem-solving, and decision-making skills, and learn to work independently as well as cooperatively with others, these factors should be taken into consideration when deciding what the assessment scheme should be.

One approach that is a natural fit with case-based learning is the use of self-evaluation and peer feedback forms. These instruments can be developed and used effectively to encourage students critically to evaluate the contributions they and their classmates have made in case analysisindividually, in groups, and in the whole class discussion. In addition to a checklist of items focusing on such factors as problem-solving, decisionmaking, cooperative learning, and communication skills and strategies, a few open-ended questions could be included to encourage students to reflect on the strengths and weaknesses of their contributions or those of their classmates. This could be supplemented with regular entries in a reflective journal. The self-evaluation and peer feedback forms could be placed in each student's portfolio, along with their journal, so they could track their progress throughout the semester. In this approach the students are actively involved in the assessment of what they have learned and contributed, just as they are encouraged to assume an active, responsible role during the analysis of the case.

Teachers may also provide feedback on student performance on oral or written case analysis, taking into consideration such elements as the student's ability to state problems and issues clearly, use sound logic and argument, make appropriate reference to readings / theory, demonstrate consistency between analysis and recommendations, and propose reasonable solutions.

An important responsibility of the case teacher is constantly to assess where the students are and to develop ways to help them best learn through cases. By spending the time and effort necessary to create appropriate assessment tools and strategies for case-based learning, the students will better understand what is expected of them and realize that this mode of learning is an important part of their course.

\section{What is the Future of Decision Cases in TESOL Teacher Education Programs?}

In spite of its limitations I believe that the case method can be a powerful methodology in TESOL teacher education programs. For this to be realized, however, advances are urgently needed in the following areas. 
Case Materials: Development and Distribution

- the preparation of TESOL cases/teaching notes by experienced ESOL practitioners in order to document the practice of ESOL teachers locally as well as in different settings worldwide. These cases should be well written and have enough details and substance to promote multiple levels of discussion, analysis, and possible solutions;

- the publication of quality TESOL casebooks (ideally by groups of ESOL teachers, teacher educators, or researchers);

- the publication of quality cases/teaching notes in ESOL and teacher education journals or newsletters;

- the incorporation of case writing into graduate teacher education programs; for example, students could write cases based on their tutoring/teaching experience, overseas placement, and so forth;

- the preparation of videotaped cases in various ESOL contexts along with support material;

- the establishment of an international clearinghouse to collect and distribute cases that have been developed by ESOL teachers, teacher educators, and student teachers in a variety of settings;

- the recognition of case development as a legitimate academic endeavor, with appropriate rewards in the promotion system in institutions of higher education (Hutchings, 1995; Merseth, 1991a).

\section{Teaching with Cases}

- the participation of ESOL teacher educators and teachers in interdisciplinary case teaching seminars and forums (see Appendix A);

- the promotion of journal writing about case-based learning experiences among student teachers and teacher educators and the sharing of this knowledge with others through dialogue, publications, conferences, and so forth;

- the sharing of ideas about teaching/learning with TESOL cases in the form of articles in TESOL journals, presentations at conferences, and online discussions in the TESL-L network.

\section{Research}

- investigations of the use of different types of cases in TESOL teacher education courses in order better to understand what actually happens in case-based learning sessions and to maximize the experiences of those involved;

- studies of the impact of case-based learning in TESOL teacher education programs;

- investigations of different ways to evaluate and assess the performance of student teachers in case-based learning. 


\section{Conclusion}

The value of cases for TESOL teacher education lies in their potential to create a safe forum for reflection that can help induct novice or experienced teachers into the real and often troubling world of professional ESOL practice. Stepping back from a problematic situation in teaching and critically examining it from various perspectives is crucial to teacher reflection. Through the analysis of cases, teachers are encouraged to take time to reflect carefully on problematic situations in teaching ESOL, and in the process they make the vital connection between theory and practice and develop a keener awareness of the variables that can affect learning/teaching. They can also come to understand themselves better as decision-makers as they reflect on their own professional thinking and move closer to becoming more thoughtful, reflective teachers.

For case-based learning to take hold in teacher education programs in our field, however, we urgently need more dialogue between ESOL specialists and colleagues in other fields who have valuable experience in using cases in their programs. The development of cases and ways of using them in our teacher education courses must also be accompanied by a research agenda that focuses on what student teachers actually learn from different types of cases as well as the methodology that best facilitates their learning. What is exciting is that this versatile teaching tool brings with it the possibility of the revitalization of TESOL teacher education curricula. Teacher educators have a responsibility to ensure that this potential is fully realized.

\section{Acknowledgements}

The author would like to thank the TESL Canada editors and three anonymous TESL Canada reviewers for their helpful comments on this paper.

\section{The Author}

Jane Jackson is an associate professor in the English Language Teaching Unit at the Chinese University of Hong Kong. She has experience in teacher education, ESP, and ESOL in Canada, the United States, Egypt, Oman, China, and Hong Kong. Her current research interests and publications center on case-based learning in teacher education, content courses, and ESP and its implications for curriculum design. Dr. Jackson is co-author of Campus Bound: Passport to Academic Success (Nelson Canada).

\section{References}

Asbaugh, C., \& Kasten, K. (1995). Educational leadership: Case studies for reflective practice. White Plains, NY: Longman.

Christensen, C.R. (1991). Premises and practices of discussion teaching. In R. Christensen, D. Garvin, \& A. Sweet (Eds.), Education for judgment: The artistry of discussion leadership (pp. 15-36). Boston, MA: Harvard Business School Press.

Christensen, C.R., \& Hansen, A. (1994). Teaching and the case method. Boston, MA: Harvard Business School.

Cooper, J. (1995). Teachers' problem solving: A casebook of award-winning teaching cases. Needham Heights, MA: Allyn and Bacon. 
Cossom, J. (1991). Teaching from cases: Education for critical thinking. Journal of Teaching in Social Work, 5(1), 139-155.

Culbertson, J., Jacobson, P., \& Reller, T. (1960). Administrative relationships: A casebook. Englewood Cliffs, NJ: Prentice-Hall.

Doyle, W. (1990, Winter). Case methods in the education of teachers. Teacher Education Quarterly, 17(1), 7-15.

Feiman-Nemser, S. (1990). Teacher preparation: Structural and conceptual alternatives. In W. R. Houston (Ed.), Handbook of research on teacher education (pp. 212-290). New York: Macmillan.

Hammond, J. (1980). Learning by the case method. Boston, MA: Harvard Business School.

Hutchings, P. (1993). Using cases to improve college teaching: A guide to more reflective practice. Washington, DC: American Association for Higher Education.

Hutchings, P. (1995). Notes on good cases. Paper presented at a Working Conference for College Faculty, Improving Teaching and Learning Through Reflective Practice, sponsored by the American Association of Higher Education (AAHE) Teaching Initiative and the Pace University Center for Case Studies in Education, University of British Columbia.

Jackson, J. (1996a, March). Cases in ESP teacher education: Preparing for unfamiliar discourse communities. Paper presented at the 1996 American Association for Applied Linguistics conference, Chicago.

Jackson, J. (1996b, March). Empowering practitioners: The case method in ESP teacher education. Paper presented at the TESOL '96 convention, Chicago.

Jackson, J. (1996c). The case for decision cases in ESP teacher Education. ESP News, 5(20), 1, 8-10.

Kennedy, M. (1987). Inexact sciences: Professional education and the development of expertise. In E. Rothkopf (Ed.), Review of research in education (vol. 14, pp. 133-167). Washington, DC: American Educational Research Association.

Kleinfeld, J. (1990). Teaching cases in cross-cultural education. Fairbanks, AK: Center for Cross-Cultural Studies, University of Alaska.

Kleinfeld, J. (1991, April). Changes in problem solving abilities of students taught through case methods. Paper presented at the Annual Meeting of the American Educational Research Association, Chicago.

Kleinfeld, J. (1992). Learning to think like a teacher: The study of cases. In J. Shulman (Ed.), Case methods in teacher education (pp. 33-49). New York: Teachers College Press,

Knirk, F. (1991). Case materials: Research and practice. Performance Improvement Quarterly, 4(1), 73-81.

Lawrence, P. (1953). The preparation of case material. In K. Andrews (Ed.), The case method of teaching human relations and administration (pp. 215-224). Cambridge, MA: Harvard University Press.

McKeachie, W. (1986). Teaching tips: A guidebook for the beginning teacher. Lexington, MA: Heath.

McRobbie, J., \& Shulman, J. (1991). Case methods: A knowledge brief on effective teaching. San Francisco, Ca: Far West Laboratory.

Merseth, K. (1991a). The case for cases in teacher education. Washington, DC: American Association of Higher Education and the American Association of Colleges for Teacher Education.

Merseth, K. (1991b). The early history of case-based instruction: Insights for teacher education today. Journal of Teacher Education, 42(4), 243-249.

Merseth, K. (1992). Cases for decision making in teacher education. In J. Shulman (Ed.), Case methods in teacher education (pp. 50-63). New York: Teachers College Press.

Osigweh, C.A. (1989). Casing the case approach in management development. Management Development, 8, 41-57.

Plaister, T. (1993). ESOL case studies: The real world of L2 teaching and administration. Englewood Cliffs, NJ: Regents / Prentice-Hall. 
Richards, J. (1991). Reflective teaching in TESOL teacher education. In E. Sadtono (Ed.), Issues in language teacher education (vol. 30, pp. 1-19). Singapore: SEAMEO Regional Language Centre.

Richards, J., \& Lockhart, C. (1994). Reflective teaching in second language classrooms. Cambridge: Cambridge University Press.

Richards, J. (Ed.). (in press). Teaching in action: Case studies from second language classrooms. Alexandria, VA: TESOL.

Schön, D. (1983). The reflective teacher: How professionals think in action. New York: Basic Books.

Schön, D. (1987). Educating the reflective teacher. San Francisco, CA: Jossey-Bass.

Shulman, J. (Ed.). (1992). Case methods in teacher education. New York: Teachers College Press.

ShuIman, J., \& Colbert, J. (1988). The intern teacher casebook. San Francisco, CA: Far West Laboratory for Educational Research and Development.

Silverman, R., Welty, W., \& Lyon, S. (1992). Case studies for teacher problem solving. New York: McGraw-Hill.

Simmons, S. (1995, July). Teaching with Cases. Paper presented at a Working Conference for College Faculty, Improving Teaching and Learning Through Reflective Practice, sponsored by the AAHE Teaching Initiative and the Pace University Center for Case Studies in Education, University of British Columbia.

Sykes, G., \& Bird, T. (1992). Teacher education and the case idea. Review of Research in Education, 18, 457-521.

Wassermann, S. (1992). A case for social studies. Phi Delta Kappan, 73, 793-801.

Wassermann, S. (1993). Getting down to cases: Learning to teach with case studies. New York: Teachers College Press.

Wassermann, S. (1994a). Using cases to study teaching. Phi Delta Kappan, 75, 602-611.

Wassermann, S. (1994b). Introduction to case method teaching: A guide to the galaxy. New York: Teachers College Press.

Weaver, R., Kowalski, T., \& Pfaller, J. (1994). Case-method teaching. In K. Prichard \& R. McLaran Sawyer (Eds.), Handbook of college teaching: Theory and applications (pp. 171-178). Westport, CT: Greenwood Press.

Welty, W., \& Silverman, R. (1995, August). An introduction to cases. Paper presented at a Working Conference for College Faculty, Improving Teaching and Learning Through Reflective Practice, sponsored by the AAHE Teaching Initiative and the Pace University Center for Case Studies in Education, University of British Columbia.

\section{Appendix A: A Select Bibliography of Casebooks}

Although only Plaister's and Richards' casebooks are targeted at ESOL teacher educators, the others can provide a good introduction to the variety of cases that are available in general education and some of the cases may be adapted to an ESOL context.

Anson, C., Graham, J., Jolliffe, D., \& Shapiro, N. (1993). Scenarios for teaching writing: Contexts for discussion and reflective practice. Urbana, IL: National Council of Teachers of English.

Asbaugh, C., \& Kasten, K. (1995). Educational leadership: Case studies for reflective practice. New York: Longman.

Greenwood, G., \& Parkay, F. (1989). Case studies for teacher decision making. New York: Random House.

Kowalski, T. (1995). Case studies on educational administration. New York: Longman.

Kowalski, T., Weaver, R., \& Henson, K. (1990). Case studies on teaching. New York: Longman.

Kowalski, T., Weaver, R., \& Henson, K. (1994). Case studies of beginning teachers. New York: Longman.

Plaister, T. (1993). ESOL case studies: The real world of $L 2$ teaching and administration. Englewood Cliffs, NJ: Regents / Prentice-Hall.

Richards, J. (Ed.). (in press). Teaching in action: Case studies from second language classrooms. Alexandria, VA: TESOL. 
Shulman, J., \& Colbert, J. (1988). The intern teacher casebook. San Francisco, CA: Far West

Laboratory for Educational Research and Development.

Shulman, J., \& Mesa-Bains, A. (Eds.). (1990). Teaching diverse students: Cases and commentaries.

San Francisco, CA: Far West Laboratory for Educational Research and Development.

Silverman, R., Welty, B., \& Lyon, S. (1992). Case studies for teacher problem solving. New York:

McGraw Hill.

Small, R., \& Strzepek, J. (1988). A casebook for English teachers: Dilemmas and decisions. Belmont,

CA: Wadsworth.

Wassermann, S. (1993). Getting down to cases: Learning to teach with case studies. New York:

Teachers College Press.

\section{Appendix B: Case Clearinghouses}

Collection and distribution centers of cases for teacher education programs.

Case Clearinghouse

Faculty of Education

Simon Fraser University

Burnaby, BC Canada, V5A 1 S6

Fax: 604-291-3203

Telephone: 604-291-3203

Center for Case Studies in Education

School of Education

Pace University

78 North Broadway

White Plains, New York 10603 USA

Fax: 914-422-4061

Far West Laboratory for Educational

Research and Development

1855 Folsom St.

San Francisco, CA 94103 USA

Fax: 415-565-3012

The Roderick MacDougall Center for Case

Development and Teaching

Harvard University

339 Gutman Library

Cambridge, MA USA

Fax: 617-496-8051

Telephone: 617-495-3572
Case Writing Group

Washington Center for Improving the Quality of Undergraduate Education

L 2211, The Evergreen State College

Olympia, WA 98505, USA

Fax: 206-866-6794

Telephone: 206-866-6000, ext. 6608

Derek Bok Center for Teaching and Learning

Science Center 318

Harvard University

One Oxford St.

Cambridge, MA 02138 USA

International Case Clearinghouse

37 Ebury Crescent

London, ON Canada, N6C 3E1

Fax: 519-686-7332

Telephone:519-686-7250

\section{Appendix C: Working Conference on Teaching with Cases/Reflective Practice}

This annual event is organized by The American Association of Higher Education (AAHE)

Teaching Initiative and the Pace University Center for Case Studies in Education, White Plains, NY. This interdisciplinary conference is limited to 150 faculty and is held at the University of British Columbia in July-August. For information, contact:

The AAHE Teaching Initiative

One Dupont Circle, Suite 360

Washington, DC 20036 USA

Telephone: 202-293-6440

Fax: 202-293-0073 